\title{
Biological activity of Bacillus spp. evaluated on eggs and larvae of red palm weevil Rhynchophorus ferrugineus
}

\author{
Nicola Francesca - Antonio Alfonzo • \\ Gabriella Lo Verde • Luca Settanni • Milko Sinacori • \\ Paolo Lucido • Giancarlo Moschetti
}

Received: 4 November 2013 / Accepted: 18 March 2014 /Published online: 5 April 2014

(C) Springer-Verlag Berlin Heidelberg and the University of Milan 2014

\begin{abstract}
This study was conducted to characterize the Bacillus populations associated with dead Rhynchophorus ferrugineus, to develop a biological control for the red palm weevil. Dead adult beetles, collected throughout Sicily, were used for isolating internal and external spore forming bacteria (SFB) microbiota. The isolates, preliminarily allotted to the Bacillaceae family, were tested at four concentrations $\left(10^{3}\right.$ to $10^{6} \mathrm{CFU} / \mathrm{mL}$ ) for their ability to inhibit hatching of eggs of $R$. ferrugineus and were used at $10^{6} \mathrm{CFU} / \mathrm{mL}$ to monitor their insecticidal activity against 10-day-old larvae. Total amounts of SFB measured outside the skeleton and in the inners part of the beetles were 5.59-6.94 and 5.17-7.05 Log CFU/g, respectively. Hatching was markedly inhibited by nine isolates, representing nine distinct strains of seven species (Bacillus amyloliquefaciens, Bacillus cereus, Bacillus licheniformis, Bacillus megaterium, Bacillus pumilus, Bacillus subtilis, and Lysinibacillus sphaericus), especially by the strains B. pumilus GC43 and GC51, which exhibited lethal concentrations 50 (LC50) values of $1.60 \times 10^{3}$ and $9.84 \times 10^{3} \mathrm{CFU} /$ $\mathrm{mL}$, respectively. Among all the strains tested, only B. licheniformis CG62 exhibited significant insecticidal activity against red palm weevil larvae. The Bacillus isolates characterized and tested in this study inhibited the hatching of red palm weevils in a contact-dependent manner. Thus, these isolates can be used as a preventive rather than as a curative treatment.
\end{abstract}

Keywords Bacillus $\cdot$ Rhynchophorus ferrugineus $\cdot$ Hatching assays $\cdot$ Larvae $\cdot$ Palm

N. Francesca $\cdot$ A. Alfonzo $\cdot$ G. Lo Verde $\cdot$ L. Settanni $\cdot$ M. Sinacori P. Lucido $\cdot$ G. Moschetti $(\bowtie)$

Department of Agricultural and Forest Science, Università degli

Studi di Palermo, Viale delle Scienze 4, 90128 Palermo, Italy

e-mail: giancarlo.moschetti@unipa.it

\section{Introduction}

The red palm weevil Rhynchophorus ferrugineus (Coleoptera: Curculionidae), which is native to Asia and Melanesia, feeds on many species of palm trees and represents the most common insect on this host. $R$. ferrugineus lives in regions with temperate climates (Murphy and Briscoe 1999) where palm trees are common. Since the end of the second millennium, the presence of red palm weevil has been also documented in Egypt, Israel, Jordan and Palestine (Kehat 1999). The red palm weevil was first found in Europe in 1993, when the weevil was detected in Spain in the palms of the genus Phoenix from Egypt (Barranco et al. 1996). Currently, the weevil has, colonized the entire Mediterranean Basin, from Morocco to Turkey (EPPO 2007a, 2009). In Italy, the red palm weevil was found for the first time in a nursery in Pistoia (Tuscany) in 2004 (Sacchetti et al. 2005, 2006), after which, the weevil has also been detected in Sicily (Longo and Tamburino 2005), Campania (Anonimo 2005), Latium, Apulia and Sardinia (EPPO 2007b). Over the past 5 years, several palms belonging to the species Phoenix canariensis, which is spread across the Canary Islands and many regions of southern Italy (especially Sicily), were infested by the weevil and were destroyed to limit the disproportionate spread of the insect. From 1995 to 2010, infestation by the weevil destroyed almost 40,000 palms in Italy (Lo Verde et al. 2011). The weevil has spread rapidly throughout Sicily because of the numerous nurseries present in the region, and, especially because of the inadequate phytosanitary inspections preformed on imported plants. Furthermore, control measures applied on infested plants were poorly timed, which led to a massive increase in red palm weevil populations and made managing their infestation challenging.

Palms are an integral part of the Mediterranean landscape and they are key components of the nurseries. Insects that 
infect palms in nurseries are controlled mainly by the application of systemic insecticides. The red palm weevil can be monitored using pheromone-containing lure buckets or pitfall traps, and the weevil can be controlled using field sanitation and mass trapping methods with traps baited with pheromone and plant-derived semiochemicals ((4S, 5S)-4-methyl-5-nonanol) (El-Shafie et al. 2011). Several research programs have also been initiated for studying the biological control of $R$. ferrugineus. Specifically, two entomopathogenic fungi Metarhizium anisopliae and Beauveria bassiana, have been detected on the red palm weevil and tested under laboratory and field conditions (Deadman et al. 2001; Gindin et al. 2006; El Sufti et al. 2007; 2009; 2011; Sewify et al. 2009; Torta et al. 2009; Vitale et al. 2009; Dembilio et al. 2010; Güerri-Aguilló et al. 2010; 2011; Merghem 2011; Francardi et al. 2012). Red weevil infestation is also tackled using microbiological approaches. Members of the Bacillus genus are key antagonistic agents of phytophagous insects (Salama et al. 2004), and several species of this genus are routinely used in the biological control of beetles; the species are remarkably specific in targeting distinct stages of the insect's life cycle. Bacillus thuringiensis, B. popilliae, B. lentimorbus and B. sphaericus synthesize proteins with insecticidal activity (Bulla et al. 1975).

Based on these findings, we isolated and characterized bacteria of the Bacillaceae family from dead adults red palm weevils and conducted preliminary tests to measure the capacity of these bacteria to inhibit the hatching of $R$. ferrugineus eggs and to kill weevil larvae.

\section{Materials and methods}

\section{Sampling}

From each sampling area (Table 1), ten dead adult weevils with no detectable signs of fungal infection were collected from palms growing in urban green areas of Sicily affected by $R$. ferrugineus. The sampling period lasted from 21 November 2007 to 4 March 2008. The beetles were stored individually in sterile plastic containers $(100 \mathrm{~mL})$ at $18{ }^{\circ} \mathrm{C}$ until being used for isolating bacteria.

\section{Microbiological analysis}

From the collected beetles, exogenous and endogenous spore-forming bacteria (SFB) were isolated. Exogenous SFB were obtained by placing the insects in sterile flasks containing sterile Ringer's solution (Sigma-Aldrich, Milan, Italy) at a final ratio of $1: 10(\mathrm{w} / \mathrm{v})$ and shaking for $10 \mathrm{~min}$ at $150 \mathrm{rpm}$. To isolate endogenous SFB, the same beetles
Table 1 Description of the samples of red palm weevil and sporeforming bacteria concentration

\begin{tabular}{llll}
\hline Site (Sicily, Italy) & Samples & $\begin{array}{l}\text { Spore-forming bacteria } \\
\text { concentration }\end{array}$ \\
\cline { 2 - 4 } & & $\begin{array}{l}\text { Exogenous Log } \\
\text { (CFU/g) }\end{array}$ & $\begin{array}{l}\text { Endogenous Log } \\
\text { (CFU/g) }\end{array}$ \\
\hline Agrigento & 1 to 10 & $6.78 \pm 1.45^{\text {a B }}$ & $7.05 \pm 1.56^{\text {a B }}$ \\
Catania & 11 to 20 & $6.49 \pm 0.88^{\text {a B }}$ & $6.60 \pm 0.91^{\text {a B }}$ \\
Cinisi (PA) & 21 to 30 & $6.34 \pm 0.46^{\text {a B }}$ & $6.43 \pm 0.51^{\text {a B }}$ \\
Marsala (TP) & 31 to 40 & $6.37 \pm 0.57^{\text {a B }}$ & $6.20 \pm 0.68^{\text {a B }}$ \\
Mazara del Vallo (TP) & 41 to 50 & $6.94 \pm 0.78^{\text {a B }}$ & $6.59 \pm 0.38^{\text {a B }}$ \\
Messina & 51 to 60 & $6.71 \pm 0.82^{\text {a B }}$ & $6.81 \pm 0.63^{\text {a B }}$ \\
Palermo & 61 to 70 & $5.59 \pm 1.21^{\text {a A }}$ & $5.17 \pm 1.20^{\text {a A }}$ \\
Ragusa & 71 to 80 & $6.79 \pm 0.32^{\text {a B }}$ & $6.63 \pm 0.37^{\text {a B }}$ \\
Terrasini (PA) & 81 to 90 & $6.49 \pm 0.58^{\text {a B }}$ & $6.19 \pm 0.80^{\text {a B }}$ \\
Villagrazia di Carini (PA) & 91 to 100 & $6.50 \pm 0.53^{\text {a B }}$ & $6.61 \pm 0.42^{\text {a B }}$ \\
\hline
\end{tabular}

${ }^{*}$ Mean values are shown \pm SD (standard deviation)

The statistical significances at $P$ values of $<0.05$ are indicated by lowercase (a, b) and uppercase (A, B) letters between the lines and the columns, respectively

were used: the insects were removed from flasks and immersed in ethanol $(100 \% \mathrm{w} / \mathrm{v})$ and then their surfaces were sterilized using a Bunsen burner (Khiyami and Alyamani 2008). Thereafter, the samples were transferred to sterile bags containing sterile Ringer's solution and homogenized using a stomacher (BagMixer ${ }^{\circledR} 400$, Interscience, Saint Nom, France) at the highest speed setting until the exoskeleton dissolved completely. All cell suspensions were heated at $85{ }^{\circ} \mathrm{C}$ for $15 \mathrm{~min}$ and then diluted serially (1:10) in Ringer's solution; $0.1 \mathrm{~mL}$ aliquots of the cell suspensions were spread on plates of Nutrient Agar (NA) (Oxoid, Basingstoke, UK) and incubated at $32{ }^{\circ} \mathrm{C}$ for $48 \mathrm{~h}$. The analysis was performed in duplicate. Furthermore, isolation tests were performed on PDA (Potato dextrose agar, Oxoid) at $27{ }^{\circ} \mathrm{C}$ for 2 weeks to confirm the absence of entomopathogenic fungi.

Isolation and identification of spore-forming bacteria (SFB)

Based on the different appearance (shape, color, edge and elevation), colonies were picked randomly from count plates, transferred to the corresponding broth media and purified by repeated sub-culturing. Gram staining was performed as reported by Gregersen (1978), and catalase test was determined by transferring fresh colonies from a Petri dish to a glass slide and adding $5 \% \mathrm{H}_{2} \mathrm{O}_{2}(\mathrm{v} / \mathrm{v})$. The SFB were identified according to the method of Gordon (1974) and stored in glycerol stocks at $-80{ }^{\circ} \mathrm{C}$ until analysis. 
Bioassays on eggs and larvae

Eggs of $R$. ferrugineus were obtained from adults reared in the laboratory of the Department Agricultural and Forest Science, University of Palermo. Newly hatched adults (5-10), both females and males, were placed in rearing boxes and provided pieces of apple to eat. We started collecting eggs after 3 weeks because the preoviposition period lasts for 6 days, the first eggs are laid after $2-3$ days, and the maximum number of eggs per female has been recorded after $16 \mathrm{~d}$ (Caldarella, unpublished observations). After 3 weeks, the ovipositing females were placed in new boxes daily with fresh pieces of apple and 24-hour-old eggs were collected for treatments. Before placing the eggs in Petri dishes, their surfaces were disinfected by immersing the eggs for $5 \mathrm{~min}$ in a $5 \%$ sodium hypochlorite solution and then rinsing them with sterile distilled water.

Tests were also performed on 10-day-old larvae obtained from the eggs, which were collected as described above. Larvae were reared individually and fed small amounts of apple (approximately $1 \mathrm{~g}$ ).

The eggs and larvae were placed on absorbent paper (moistened with sterile water to prevent dehydration) within sterile Petri dishes and maintained at $25^{\circ} \mathrm{C}$ and $75 \%$ relative humidity (RH) throughout all experiments. SFB isolates were grown overnight $(\mathrm{O} / \mathrm{N})$ after streaking onto NA plates, and a colony of each isolate was grown $\mathrm{O} / \mathrm{N}$ under shaking at $120 \mathrm{rpm}$ at $32{ }^{\circ} \mathrm{C}$ in $150 \mathrm{~mL}$ of nutrient broth (NB). The cells were washed twice in Ringer's solution (5 min at $14000 \mathrm{rpm}$ ) and diluted to obtain scalar dilutions $\left(10^{6}, 10^{5}, 10^{4}\right.$, and $\left.10^{3} \mathrm{CFU} / \mathrm{mL}\right)$. The eggs (10/dish) were placed on absorbent paper and cell suspensions $(2 \mathrm{~mL})$ were sprayed on their surface. Ringer's solution was used as negative control. Petri dishes were sealed with Parafilm to prevent evaporation and dehydration. Because most eggs hatch in 3-4 days (Kaakeh 2005), the dishes containing eggs were placed at $25^{\circ} \mathrm{C}$ and $75 \% \mathrm{RH}$ for 6 days and the hatching of eggs was recorded daily.

To conduct tests on larvae, $1 \mathrm{~mL}$ of each bacterial strain suspension $\left(10^{6} \mathrm{CFU} / \mathrm{mL}\right)$ or control Ringer's solution was added to the piece of apple. Larval mortality was recorded daily for 10 days.

In all tests and controls, we used 30 eggs or larvae (ten instars for three repetitions).

Phenotypic and genotypic characterization of SFB that inhibit hatching

For preliminary differentiation of the bacteria that inhibited hatching, all isolates were grouped phenotypically according to the method of Gordon (1974) and then identified at the species level using various molecular approaches. All isolates were first differentiated genotypically based on randomly amplified polymorphic DNA (RAPD), as reported by
Sinacori et al. (2014). DNA was extracted using InstaGene $^{\mathrm{TM}}$ Matrix (Bio-Rad Laboratories, Hercules, CA) according to the supplier's recommendations. All isolates were also analyzed using repetitive DNA element-PCR (rep$\mathrm{PCR})$ with the $(\mathrm{GTG})_{5}$ and BOXA1R primer sets (Versalovic et al. 1994; Gevers et al. 2000) corresponding to the (GTG) and BOX-like elements in bacterial DNA, respectively. All patterns were analyzed using Gelcompare II software, version 6.5 (Applied-Maths, Sin Marten Latem, Belgium). The cluster analysis was performed using the Dice similarity coefficient and the UPGMA clustering algorithm (unweighted PairGroup Method With Arithmetic Means) with a tolerance of $2 \%$ between the bands. The primers used for amplifying the 16S rRNA gene were fD1 and rD1, which were described by Weisburg et al. (1991). The PCR mixture ( $50 \mu \mathrm{L}$ total volume) included 50 ng of target DNA, $1 \times$ Taq DNA polymerase buffer (Invitrogen, Milan, Italy), $2.5 \mathrm{mM}$ of $\mathrm{MgCl}_{2}, 250 \mu \mathrm{M}$ of each of the dNTPs, $0.2 \mu \mathrm{M}$ of each primer, and $2.5 \mathrm{U}$ of Taq DNA polymerase (Invitrogen). For PCR, we used an initial denaturing step $\left(3 \mathrm{~min}\right.$ at $\left.95^{\circ} \mathrm{C}\right)$, followed by 30 amplification cycles $\left(1 \mathrm{~min}\right.$ at $94{ }^{\circ} \mathrm{C}, 45 \mathrm{~s}$ at $54^{\circ} \mathrm{C}, 2 \mathrm{~min}$ at $72{ }^{\circ} \mathrm{C}$ ), and then a final chain-elongation step $\left(7 \mathrm{~min}\right.$ at $\left.72{ }^{\circ} \mathrm{C}\right)$; reactions were performed in a Biometra T1 Thermocycler (Biometra GmbH, Goettingen, Germany). PCR products were resolved by electrophoresis on agarose $(1.5 \% \mathrm{w} / \mathrm{v})$ gels $(100 \mathrm{~V}, 2 \mathrm{~h})$; the gels were stained with SYBR ${ }^{\circledR}$ Safe DNA gel stain (Invitrogen), and bands were visualized under UV illumination. Amplicons (approximately 1600-bp long) were purified using the QIAquick purification kit (Qiagen S.p.a., Milan, Italy) and sequenced using the same primers employed for PCR amplification. DNA sequencing reactions were performed by PRIMM (Milan, Italy). The sequences were compared using BLAST search in the GenBank/EMBL/DDBJ database (Altschul et al. 1997). To further characterize the species at the level of bacterial strains belonging to the genus Bacillus, 16S rRNA gene-restriction fragment length polymorphism (RFLP) analysis was also performed. DNA fragments were digested with the endonucleases RsaI, CfoI, and Hinfl (MBI Fermentas, St. Leon-Rot, Germany) at $37^{\circ} \mathrm{C}$ for $8 \mathrm{~h}$, and the amplicons and their restriction fragments were analyzed on agarose gels $(2.0 \%$ agarose $(\mathrm{w} / \mathrm{v})$ in $1 \times \mathrm{TBE}(89 \mathrm{mmol} / \mathrm{L}$ Trisborate, $2 \mathrm{mmol} / \mathrm{L}$ EDTA $\mathrm{pH} 8)$ ). Gels were stained with SYBR ${ }^{\circledR}$ safe DNA gel stain (Invitrogen) and bands were visualized using a UV transilluminator, and images were acquired using the Gel Doc 1000 Video Gel Documentation System (BioRad, Richmond, USA). The standard DNA ladder used was GeneRuler 50 bp DNA Ladder (MBI Fermentas).

\section{Statistical analysis}

The data on the exogenous and endogenous SFB concentrations were evaluated using analysis of variance (ANOVA) 





followed by the Tukey's test at a significance level of $P<0.05$. The analyses were conducted using PSPP v.0.7.8 (Copyright (C) 2007 Free Software Foundation, Inc.). The inhibition on hatching activity was evaluated with a Probit analysis by means of Maximum Likelihood Estimation Method, carried out by MINITAB (Minitab, Inc., State College, PA). Once obtained, the parameters useful for the probit regression line, as well as the lethal concentration $50 \%$ (LC50) and lethal concentration $90 \%$ (LCD), were calculated for the isolates that showed a significant dosage effect. These values were obtained as antilog of the predicted dose values corresponding to a mortality rate of $50 \%$ and $90 \%$, respectively. Chi-Square test was applied to evaluate the goodness of fit (Finney 1971). Fisher's exact test was applied to the data from the larvae, and the one-tailed $\mathrm{P}$ value was calculated to evaluate differences relative to control (Fisher 1954).

\section{Results}

Sampling of red palm weevils and isolation of SFB

The microbial loads of SFB (Table 1) ranged from 5.17 to 7.05 Log CFU/g. Except in the case of samples from Palermo, no statistically significant difference $(P<0.05)$ was found between the concentrations of exogenous and endogenous SFB associated with weevils from various sampling sites. Cell counts identified 644 isolates among the exogenous microbiota and 507 isolates among the endogenous microbiota. All 1,151 isolates were purified for use in the hatching assays.

The isolation tests conducted on the beetles also revealed the presence of certain saprotrophic fungi of the genus Cladosporium, Aspergillus, and Penicillium, but no colonies of entomopathogenic fungi were detected.

\section{Bioassays on eggs and larvae}

All isolates were tested for their ability to inhibit the hatching of weevil eggs, but only nine isolates produced effects that were significantly different from control. All of these active cultures were part of the exogenous microbiota of insects obtained from distinct green areas of Sicily. The isolates that exhibited the highest inhibitory activities at the maximal microbial concentration tested $\left(10^{6} \mathrm{CFU} / \mathrm{mL}\right)$ were CG64 and GC51, which caused an average number of unhatched eggs in each replication test of 8.67 and 8.33 , respectively. Only one isolate (GC63) did not inhibit hatching at $10^{3} \mathrm{CFU} / \mathrm{mL}$, although this isolate was clearly effective at higher concentrations (Table 2). The results of the probit analysis revealed that all isolates except GC61 inhibited hatching significantly in a dose-dependent manner. The likelihood-ratio Chi-Square test showed a good fit of the probit model for all the isolates. Among the isolates, GC43 had the lowest LC50 and GC65 the highest LC50, whereas the lowest LC90 was recorded for the isolate GC51 and the highest for GC49 and GC65 (Table 2).

The tests on the larvae showed that a significant difference between treated and control larvae was only found for the strain GC62 (Table 3).

Phenotypic and genotypic identification of active strains

The nine isolates were first characterized morphologically based on colony appearance and cell shape. The colonies showed differences in color and shape and in morphology and the swelling of spores. The biochemical tests divided the nine isolates into seven groups (Table 4). The nine isolates were further characterized by genotypic techniques. The RAPD-PCR analysis was able to separate the isolates in seven groups (Table 5), whereas rep-PCR recognized five different clusters, showing a lower discriminatory power than the first technique. Considering the various phenotypic (morphological and biochemical) traits, the disparities in the level of inhibition, the different geographical origins, and the results of genotypic characterization, the nine isolates were considered as nine distinct strains. Comparing sequences directly using BLAST search (Table 5) identified only one strain at the species level: Lysinibacillus fusiformis strain GC63. For the other strains, comparing their RFLP profiles with those reported by Jeyaram et al. (2011) identified the following species: B. amyloliquefaciens (strains GC25 and GC49), B. cereus (strain GC65), B. subtilis (strain GC64), B. pumilus (strains $\mathrm{GC} 43$ and 51), B. licheniformis (strain GC62), and B. megaterium (strain GC61).

Table 3 Test on neonate larvae of $R$. ferrugineus treated with $10^{6} \mathrm{CFU} /$ $\mathrm{mL}$ concentrated strains

\begin{tabular}{|c|c|c|c|c|c|}
\hline \multirow[b]{2}{*}{ Strains } & \multicolumn{2}{|l|}{ Mean $\pm \mathrm{SE}$} & \multicolumn{2}{|c|}{ Total died larvae } & \multirow[t]{2}{*}{$\mathrm{P}$ value } \\
\hline & Control & Treated & Control & Treated & \\
\hline $\mathrm{GC} 25$ & $3.67 \pm 0.88$ & $2.33 \pm 0.67$ & 11 & 7 & 0.1993 \\
\hline GC43 & $3.67 \pm 0.67$ & $3.33 \pm 0.33$ & 11 & 10 & 0.5000 \\
\hline GC49 & 0.00 & $0.33 \pm 0.33$ & 0 & 1 & 0.5000 \\
\hline GC51 & 0.00 & 0.00 & 0 & 0 & 1.0000 \\
\hline GC61 & $1.67 \pm 0.88$ & $0.33 \pm 0.33$ & 5 & 1 & 0.0973 \\
\hline GC62 & 0.00 & $2.00 \pm 1.00$ & 0 & 6 & 0.0119 \\
\hline GC63 & $1.33 \pm 0.67$ & $0.33 \pm 0.33$ & 4 & 1 & 0.1766 \\
\hline GC64 & 0.00 & $0.67 \pm 0.33$ & 0 & 2 & 0.2458 \\
\hline GC65 & $1.67 \pm 0.88$ & $0.33 \pm 0.33$ & 5 & 1 & 0.0973 \\
\hline
\end{tabular}

* One tailed $P$-value obtained by Fisher's exact test 
Table 4 Morphological and biochemical characterization of nine cultures of aerobic spore-forming bacilli biologically active against the egg hatching of red palm weevil

\begin{tabular}{|c|c|c|c|c|c|c|c|c|c|}
\hline \multirow[t]{2}{*}{ Characters } & \multicolumn{9}{|c|}{ Bacterial strain tested } \\
\hline & $\mathrm{GC} 25$ & GC43 & GC49 & GC51 & GC61 & GC62 & GC63 & GC64 & G65 \\
\hline \multicolumn{10}{|l|}{ Colony } \\
\hline Color & Beige & Beige & White & Beige & White & Beige & White & White & White \\
\hline Shape & Round & Irregular & Round & Irregular & Round & Irregular & Irregular & Round & Round \\
\hline Margin & Entire & Entire & Entire & Entire & Entire & Irregular & Entire & Entire & Irregular \\
\hline Elevation & Raised & Raised & Raised & Raised & Raised & Raised & Raised & Raised & Flat \\
\hline \multicolumn{10}{|c|}{ Cell and spore morphology } \\
\hline Vegetative cells & Rod & Rod & Rod & Rod & Rod & Rod & Rod & Rod & Rod \\
\hline Spores & Cylindrical & Cylindrical & Ellipsoidal & Cylindrical & Ellipsoidal & Cylindrical & Ellipsoidal & Ellipsoidal & Ellipsoidal \\
\hline Swelling the sporangium & - & - & - & - & - & - & + & - & - \\
\hline \multicolumn{10}{|l|}{ Biochemical tests } \\
\hline Catalase & + & + & + & + & + & + & + & + & + \\
\hline Gram reaction & + & + & + & + & + & + & + & + & + \\
\hline Anaerobic growth & - & - & - & - & + & - & + & + & + \\
\hline V-P reaction & + & + & + & + & - & - & - & - & + \\
\hline Methyl red tests & + & + & + & + & - & - & - & - & + \\
\hline Growth in $7 \% \mathrm{NaCl}$ & + & + & + & + & + & + & + & + & + \\
\hline Gas from glucose & - & - & - & - & - & - & - & - & - \\
\hline Starch hydrolysis & + & - & + & - & + & - & + & + & - \\
\hline Use of citrate & + & + & + & + & + & + & + & - & - \\
\hline Casein decomposing & + & + & + & + & + & + & + & + & + \\
\hline Gelatin liquefaction & + & + & + & + & + & + & + & + & + \\
\hline Growth at $50{ }^{\circ} \mathrm{C}$ & + & + & + & + & - & + & - & - & - \\
\hline Hydrolysis of urea & - & - & + & - & + & + & + & + & variable \\
\hline Hemolysis of $5 \%$ blood & - & variable & - & variable & + & variable & + & - & + \\
\hline Groups & $\mathbf{I}$ & II & I & II & III & IV & $\mathbf{V}$ & VI & VII \\
\hline
\end{tabular}

\section{Discussion}

The red palm weevil is the most harmful pest of palm trees that causes considerable damages to both the economy and the landscape in the Mediterranean area (Barranco et al. 1996;
Dembilio and Jacas 2012). Most of the physical and chemical methods used to limit the spread of this insect have proven almost ineffective; this may be because the larvae, which mainly cause the damage, reside inside the trunk and are thus protected. Natural pathogens that curtail the spread of

Table 5 Molecular identification of spore forming bacteria

\begin{tabular}{|c|c|c|c|c|c|c|}
\hline Strain & Phenotypic cluster & RAPD cluster & GTG/BOXA1R cluster & Identification by $16 \mathrm{~S}$ and BLAST search & Final identification by RFLP & Acc. No. \\
\hline GC25 & I & 1 & 1 & B. subtilis / B. amyloliquefaciens & B. amyloliquefaciens & KF158226 \\
\hline GC43 & II & 2 & 1 & B. pumilus & B. pumilus & KF158227 \\
\hline GC49 & I & 3 & 1 & B. subtilis / B. amyloliquefaciens & B. amyloliquefaciens & KF158228 \\
\hline GC51 & II & 2 & 2 & B. pumilus & B. pumilus & KF158229 \\
\hline GC61 & III & 4 & 3 & B. megaterium & B. megaterium & KF158230 \\
\hline GC62 & IV & 5 & 1 & B. licheniformis & B. licheniformis & KF158231 \\
\hline GC63 & $\mathrm{V}$ & 6 & 4 & Lysinibacillus sphaericus & - & KF158232 \\
\hline GC64 & VI & 7 & 1 & B. subtilis / B. amyloliquefaciens & B. subtilis & KF158233 \\
\hline GC65 & VII & 7 & 5 & B. cereus / B. thuringiensis & B. cereus & KF158234 \\
\hline
\end{tabular}


$R$. ferrugineus appear to be more effective in reducing weevil populations than in protecting plants that are already infested (Salama et al. 2004; Son et al. 2004; Dembilio et al. 2010; ElSufty et al. 2011). A female red palm weevil lays approximately 200 eggs, which, in newly colonized palms, are laid in small cavities in the trunk or at the damaged surfaces of the leaves (Hutson 1922). Consequently, unlike the larvae that complete their life cycle inside the palms, the eggs are found in the external parts of the plant and may be easier to access than the larvae.

Our objectives in this study were to isolate and identify SFB capable of inhibiting the hatching of eggs of $R$. ferrugineus. Unlike previous studies in which bacteria were collected from larvae (Salama et al. 2004; Khiyami and Alyamani 2008; Butera et al. 2012), we isolated bacteria from dead adult insects.

From a total of 1,151 isolates tested, nine strains belonging to distinct species showed a clear anti-hatching activity. Bacillus species are commonly isolated from beetles (Sezen et al. 2008). Inhibition of egg hatching was found to be strain specific. The strain B. pumilus GC43 showed the lowest LC50, but not the highest mortality at the maximal concentration tested. B. subtilis GC64 also showed interesting results; this species has not been previously reported to inhibit the hatching of eggs of $R$. ferrugineus, although its inhibitory effects on larvae and pupae of this beetle have been described (Salama et al. 2004).

Bacillus subtilis has been employed as a biopesticide against phytophagous lepidopteran that infests cotton (Bora et al. 1994); thus, the use of this bacterial species in biological control is not new. Furthermore, although B. subtilis has not been reported to produce biopesticides with as broad a spectrum of action as $B$. thuringiensis, $B$. subtilis can persist in the environment at higher concentrations than $B$. thuringiensis. Thus, the demonstrated antagonistic actions of $B$. subtilis may last longer than those of $B$. thuringiensis.

Two strains with interesting properties belong to B. pumilus, a species spread in the environment but not specifically related to insects (Son et al. 2004). One strain was identified as Lysinibacillus sphaericus after differentiating it from L. fusiformis, based on the ability to hydrolyze urea. These two species, formerly assigned to Bacillus, have been recently transferred to the new genus Lysinibacillus (Ahmed et al. 2007). L. sphaericus is commonly used in the biological control of various families of insects (Alexander and Priest 1990; Woodburn et al. 1995; Rippere et al. 1997; Salama et al. 2004).

One active strain belonged to the species $B$. cereus, which kills various insect pests at all developmental stages, including eggs and adults of phytophagous insects and early stage larvae of many insects (Sezen et al. 2005; Pena et al. 2006; Sezen et al. 2008; Merghem 2011). B. cereus is used commonly in agriculture because of its low environmental impact.
Using bacteria to control phytophagous insects is a critical part of numerous agricultural applications. The basic requirements for using bacteria are the absence of antagonistic activities on useful insects and safety for the agricultural environment.

The percentage of strains that inhibited the hatching of the eggs of $R$. ferrugineus was extremely low among the isolates collected $(0.78 \%)$, which indicates that this property is rare in nature. The statistical analysis of results obtained with the high concentration used on the larvae showed that only the strain GC62 exhibited an entomopathogenic effect on $R$. ferrugineus larvae, suggesting that actions of all the tested bacteria are contact dependent. Further studies are required to more fully characterize the active compounds produced by these bacteria and the mode of action of the strains that are most effective in inhibiting the hatching of red palm weevil eggs.

Acknowledgments The authors are grateful to Dr. C. Caldarella and Dr. C. Sannino for their help with the capture and breeding of red palm weevils and microbiological analysis, respectively. This work was financially supported by Presidenza Regione Sicilia (Italy) and University of Palermo through the project FITOPALMINTRO SICILIA.

\section{References}

Ahmed I, Yokota A, Yamazoe A, Fujiwara T (2007) Proposal of Lysinibacillus boronitolerans gen. nov., sp. nov., and transfer of Bacillus fusiformis to Lysinibacillus fusiformis comb. nov. and Bacillus sphaericus to Lysinibacillus sphaericus comb. nov. Int J. Syst Evol Microbiol 57:1117-1125

Alexander B, Priest FG (1990) Numerical classification and identification of Bacillus sphaericus including some strains pathogenic for mosquito larvae. J Gen Microbiol 136:367-376

Altschul SF, Madden TL, Schaffer AA, Zhang J, Zhang Z, Miller W, Lipman DJ (1997) Grapped BLAST and PSI-BLAST: a new generation of protein database search programs. Nucleic Acids Res 25: 3389-3402

Anonimo (2005) Diffusione del punteruolo rosso in Italia. Info Agr 30:74

Barranco P, De La Pana J, Cabello T (1996) El picodo rojo de las palmeras, Rhynchophorus ferrugineus (Olivier), nueva plaga in Europa. Phytoma Esp 67:36-40

Bora RS, Murty MG, Shenbagarathi R, Sekar V (1994) Introduction of a lepidopteran-specific insecticidal protein gene of Bacillus thuringiensis subsp. kurstaki by conjugal transfer into Bacillus megaterium strain that persists in cotton phyllosphere. Appl Environ Microb 60:214-222

Bulla LA Jr, Rhodes RA, Julian GS (1975) Bacteria as insect pathogens. Annu Rev Microbiol 29:163-190

Butera G, Ferraro C, Colazza S, Alonzo G, Quatrini P (2012) The culturable bacterial community of frass produced by larvae of Rhynchophorus ferrugineus Olivier (Coleoptera: Curculionidae) in the Canary island date palm. Lett Appl Microbiol 54(6):530-536

Deadman ML, Azam KM, Ravzi SA, Kaakeh W (2001) Preliminary investigation into the biological control of the red palm weevil using Beauveria bassiana. Proceedings of the Second International Conference on Date Palm, Al-Ain, UAE. March 25-27: 225-232

Dembilio O, Jacas JA (2012) Bio-ecology and integrated management of the red palm weevil, Rhynchophorus ferrugineus (Coleoptera: 
Curculionidae), in the region of Valencia (Spain). Hell Plant Prot J 5: $1-12$

Dembilio Ó, Quesada-Moraga E, Santiago-Álvarez C, Jacas JA (2010) Potential of an indigenous strain of the entomopathogenic fungus Beauveria bassiana as a biological control agent against the Red Palm Weevil, Rhynchophorus ferrugineus. J Invertebr Pathol 104(3):214-221

El-Shafie HAF, Faleiro JR, Al-Abbad AH, Stoltman L, Mafra-Neto A (2011) Bait-free attract and kill technology (Hook ${ }^{\mathrm{TM}}$ RPW) to suppress red palm weevil, Rhynchophorus ferrugineus (Coleoptera: Curculionidae) in date palm. Fla Entomol 94(4):774 778

El-Sufty R, Al-Awash SA, Al Amiri AM, Shahdad AS, Al Bathra AH, Musa SA (2007) Biological control of red palm weevil, Rhynchophorus ferrugineus (Col.: Curculionidae) by the entomopathogenic fungus Beauveria bassiana in United Arab Emirates. Acta Hortic (ISHS) 36:399-404

El-Sufty R, Al-Awash SA, Al Bgham S, Shahdad AS, Al Bathra AH (2009) Pathogenicity of the fungs Beauveria bassiana (Bals.) Vuill to the red palm weevil, Rhynchophorus ferrugineus (Oliv.) (Col.: Curculionidae) under laboratory and field conditions. Egypt J Biol Pest Control 19(1):81-86

El-Sufty R, Al Bgham S, Al-Awash SA, Shahdad AS, Al Bathra AH (2011) A trap for auto-dissemination of the entomopathogenic fungus Beauveria bassiana by the red palm weevil adults in date palms plantations. Egypt J Biol Pest Control 21(2):271-276

EPPO (2007a). First report of Rhynchophorus ferrugineus in Turkey. EPPO Reporting Service 1:2

EPPO (2007b) Further reports of Rhynchophorus ferrugineus in Puglia and Sardegna, Italy. EPPO Reporting Service 1:2

EPPO (2009) First record of Rhynchophorus ferrugineus in Morocco. EPPO Reporting Service 1:2

Finney DJ (1971) Probit Analysis (3rd edition). Cambridge University Press, Cambridge, UK

Fisher RA (1954) Statistical Methods for Research Workers. Oliver and Boyd

Francardi V, Benvenuti C, Roversi PF, Rumine P, Barzanti G (2012) Entomopathogenicity of Beauveria bassiana (Bals.) Vuill. and Metarhizium anisopliae (Metsch.) Sorokin isolated from different sources in the control of Rhynchophorus ferrugineus (Olivier) (Coleoptera Curculionidae). REDIA 95:49-55

Gevers D, Huys G, Devlieghere F, Uyttendaele M, Debevere J, Swings J (2000) Isolation and identification of tetracycline resistant lactic acid bacteria from pre-packed sliced meat products. Syst Appl Microbiol 23:279-284

Gindin G, Levski S, Glazer I, Soroker V (2006) Evaluation of the entomopathogenic fungi Metarhizium anisopliae and Beauveria bassiana against the red palm weevil Rhynchophorus ferrugineus. Phytoparasitica 34(4):370-379

Gordon RE (1974) The genus Bacillus. In: Laskin AI, Lechevalie HA (eds) Handbook of microbiology, vol 1. Organisms in Microbiology

Gregersen T (1978) Rapid method for distinction of gram-negative from gram-positive bacteria. Eur J Appl Microbiol Biotechnol 5:123-127

Güerri-Agulló B, Gómez-Vidal S, Asensio L, Barranco P, Lopez-Llorca LV (2010) Infection of the red palm weevil (Rhynchophorus ferrugineus) by the entomopathogenic fungus Beauveria bassiana: A SEM study. Microsc Res Tech 73(7):714-725

Güerri-Agulló B, López-Follana R, Asensio L, Barranco P, Lopez-Llorca LV (2011) Use of a solid formulation of Beauveria bassiana for biocontrol of the red palm weevil (Rhynchophorus ferrugineus) (Coleoptera: Dryophthoridae) under field conditions in SE Spain. Fla Entomol 94(4):737-747

Hutson JC (1922) The Red Weevil of Palm Weevil (Rhynchophorus Ferrugineus). Trop Agr 9(4):249-254

Jeyarama K, Romia W, Singha TA, Adewumib GA, Basantia K, Oguntoyinbob FA (2011) Distinct differentiation of closely related species of Bacillus subtilis group with industrial importance. J Microbiol 87:161-164

Kaakeh W (2005) Longevity, fecundity, and fertility of the red palm weevil, Rhynchophorus ferrugineus Olivier (Coleoptera: Curculionidae) on natural and artificial diets. Emirates Journal Agriculture Science 17:23-33

Kehat M (1999) Threat to Date Palms in Israel, Jordan and the Palestinian Authority by the Red Palm Weevil, Rhynchophorus ferrugineus. Phytoparasitica 27:107-108

Khiyami M, Alyamani E (2008) Aerobic and facultative anaerobic bacteria from gut of red palm weevil (Rhynchophorus ferrugineus). Afr J Biotechnol 7(10):1432-1437

Lo Verde G, La Mantia G, Griffo R (2011) El estado de la infestacion por Rhynchophorus ferrugineus (Olivier) en Italia y los resultados de las pruebas de cirurgia arborea para el control de palmeras infestadas. Phytoma Esp 226:85-88

Longo S, Tamburino V (2005) Gravi infestazioni del punteruolo rosso della palma. Info Agr 30:73-74

Merghem A (2011) Susceptibility of the red palm weevil, Rhynchophorus ferrugineus (olivier) to the green muscardine fungus, Metarhizium anisopliae (metsch.) in the laboratory and in palm trees orchards. Egyptian J Biol Pest Co 21(2):179-183

Murphy ST, Briscoe BR (1999) The red palm weevil as an alien invasive: biology and the prospects for biological control as a component of IPM. Biocontrol News Inf 20:35-46

Pena G, Miranda-Rios J, de la Riva G, Pardo-Lopez L, Soberon M, Bravo A (2006) A Bacillus thuringiensis S-layer protein involved in toxicity against Epilachna varivestis (Coleoptera : Coccinellidae). Appl Environ Microbiol 72:353-360

Rippere KE, Johnson JL, Yousten AA (1997) DNA similarities among mosquito pathogenic and non-pathogenic strains of Bacillus sphaericus. Int J Syst Bacteriol 47:214-216

Sacchetti P, Camera A, Granchietti A, Rosi MC, Marzialetti P (2005) Prima segnalazione in Italia del Curculionide delle palme, Rhynchophorus ferrugineus. Notiziario del centro Sperimentale per il Vivaismo di Pistoia 144(5-6):6-9

Sacchetti P, Camera A, Granchietti A, Rosi MC, Marzialetti P (2006) Identificazione, biologia e diffusione del Curculionide delle palme, Rhynchophorus ferrugineus. Inf Fitopatol 20(6): $35-40$

Salama HS, Foda MS, El-Bendary MA, Abdel-Razek A (2004) Infection of red palm weevil, Rhynchophorus ferrugineus, by spore-forming bacilli indigenous to its natural habitat in Egypt. J Pest Sci 77(1):2732

Sewify GH, Belal MH, Al-Awash SA (2009) Use of the entomopathogenic fungus, Beauveria bassiana for the biological control of the red palm weevil, Rhynchophorus ferrugineus Olivier. Egypt J Biol Pest Co 19(2):157-163

Sezen K, Demir I, Katt H, Demirbag Z (2005) Investigations on bacteria as a potential biological control agent of summer chafer, Amphimallon solstitiale L. (Coleoptera : Scarabaeidae). J Microbiol 43:463-468

Sezen K, Kati H, Nalcacioglu R, Muratoglu H, Demirbag Z (2008) Identification and pathogenicity of bacteria from European shothole borer, Xyleborus dispar Fabricius (Coleoptera : Scolytidae). Ann Microbiol 58:173-179

Sinacori M, Francesca N, Alfonzo A, Cruciata M, Sannino C, Settanni L, Moschetti G (2014) Cultivable microorganisms associated with honeys of different geographical and botanical origin. Food Microbiol 38:284-294

Son HJ, Kim G, Park YK (2004) Isolation and identification of feather-degrading bacteria for biotechnological applications of keratinaceous protein waste. J Life Sci 14:229-234

Torta L, Leone V, Caldarella CG, Lo Verde G, Burruano S (2009) Microrganismi fungini associati a Rhynchophorus ferrugineus (Olivier) in Sicilia e valutazione dell'efficacia entomopatogena di 
un isolato di Beauveria bassiana (Bals.) Vuill (2009). Osservazioni preliminari. Micol Ital 38(2):49-55

Versalovic J, Schenider M, de Bruin FJ, Lupski JR (1994) Genomic fingerprinting of bacteria using repetitive sequence-based polymerase chain reaction. Method Mol Cell Biol 5:25-40

Vitale A, Leone V, Torta L, Burruano S, Polizzi G (2009) Prove preliminari di lotta biologica con Beauveria bassiana e Metarhizium anisopliae nei confronti del punteruolo rosso. In
Regione Siciliana - Assessorato Agricoltura e Foreste. La ricerca scientifica sul Punteruolo rosso e gli altri fitofagi delle palme in Sicilia, Palermo, Italy. pp. 1:169-72

Weisburg WG, Barns SM, Pelletier DA, Lane DL (1991) 16S ribosomal DNA amplification for phylogenetic study. J Bacteriol 173:697-703

Woodburn MA, Yousten AA, Hilu H (1995) Random amplified polymorphic DNA fingerprinting of mosquito-pathogenic and nonpathogenic strains of Bacillus sphaericus. Int J Syst Bacteriol 45:212-217 